\title{
A cryptotephra record from the Lake Victoria sediment core record of Holocene palaeoenvironmental change
}

\section{Prof Christine S. Lane}

Department of Geography, University of Cambridge, Downing Place, Cambridge, CB2 3EN, UK. csl44@cam.ac.uk, +44 (0)1223 330242

Dr Catherine Martin-Jones

Department of Geography, University of Cambridge, Downing Place, Cambridge, CB2 3EN, UK. cmm206@cam.ac.uk

Prof Thomas C. Johnson

Dept. of Geosciences, University of Massachusetts Amherst, Amherst, MA 01003, USA

and

Large Lakes Observatory, University of Minnesota Duluth, 2205 E. 5th Street, Duluth, MN 55812, USA.

tcj@d.umn.edu

\section{$\underline{\text { Abstract }}$}

The sediment record from Lake Victoria is an important archive of regional environmental and climatic conditions, reaching back more than 15,000 cal. years before present (15 ka BP). As the largest lake by area in East Africa, its evolution is key to understanding regional palaeohydrological change during the Late Pleistocene and Holocene, including controls on the Nile River flow. As well as important palaeoenvironmental proxies, the lake contains a unique record of explosive volcanism from the central Kenyan Rift, in the form of fine-grained volcanic ash (tephra) layers, interpreted as airfall deposits. In the V95-1P core, collected from the central northern basin of the lake, tephra layers vary in concentration from 10's to 10's of 1000's of glass shards per gram of sediment. None of the tephra are visible to the naked eye, and have only been revealed through careful laboratory processing. Compositional analyses of tephra glass shards has allowed the tephra layers to be correlated to previously unrecognized eruptions of Eburru volcano around 1.2 and $3.8 \mathrm{ka}$, and Olkaria volcano, prior to $15 \mathrm{ka}$. These volcanoes lie $\sim 300 \mathrm{~km}$ east of the core site in the Kenyan Rift. Our results highlight the potential for developing cryptotephra analysis as a key tool in East African palaeolimnological research. Tephra layers offer opportunities for precise correlation of palaeoenvironmental sequences, as well as windows into the eruption frequency of regional volcanoes and the dispersal of volcanic ash.

\section{Keywords}

\section{Tephra}

Central Kenyan Rift

Volcanism

Holocene palaeoenvironment

Cryptotephra 
1. Introduction

\subsection{Lake Victoria}

As Africa's largest lake by surface area, Lake Victoria plays a significant role in past and present hydrological processes of equatorial East Africa as well as much of north-eastern Africa via its contribution to local rainfall and to Nile River flow. The development of the lake through time is therefore of significant interest to palaeoclimatologists reconstructing past environmental changes, to biologists studying endemic and evolving species of plants, fish and other organisms, and to archaeologists interested in pathways of evolution, communication and migration for early to recent hominin species (e.g. Stager et al., 1997; Verheyen et al., 2003; Tryon et al., 2016).

Lake Victoria is believed to have been formed around 400,000 years before present (400 ka BP) as a result of tectonic uplift of the western arm of the East African Rift Valley, which reversed regional drainage and back ponding in its shallow basin (Johnson et al., 2000). Despite Lake Victoria's great age, our knowledge of the lake's palaeohydrological evolution is limited to the last $\sim 18$ ka BP. Since the 1960's, multiple sediment cores have been studied, most of which extend back to a significant desiccation event, marked by vertisol formation, coincident with the global Last Glacial maximum (LGM) (e.g. Kendall, 1969; Stageret al, 1984; Johnson et al., 1996; Talbot, and Lærdal, 2000). The onset, duration and continuity of Late Pleistocene desiccation is not known, as only undated seismic profiles are available to interpret the older part of the record (Scholz et al., 1998; Johnson et al., 2000). Shallow, unstable, lacustrine conditions, possibly interrupted by more than one interval of desiccation, existed prior to $15 \mathrm{ka} \mathrm{BP}$ after which time the lake deepened and northerly overflow into the White Nile commenced (Beuning et al., 2002; Stager and Johnsonet al, 2008). Over the last century, human impacts on Lake Victoria's ecosystem include eutrophication and consequent changes in aquatic resource availability (Verschuren et al., 2008).

Understanding how Lake Victoria's evolution relates to wider East African landscapes, as well as to regional and global climate variability, demands a precise and accurate chronology and a means to make direct and robust comparisons of the Lake Victoria record to neighbouring East African Rift archives, including lake sediment sequences and archaeological sites in Uganda, Rwanda, Kenya and Tanzania.

\subsection{Tephrostratigraphy and cryptotephra in East Africa}

The potential for using far-travelled volcanic ash (tephra) layers to date and correlate East African sedimentary records has been exemplified within Pleistocene archaeological research (e.g. Tryon and McBrearty, 2002, Brown and Fuller, 2008, Blegen et al., 2015). Undisturbed, airfall-derived, visible tephra layers provide isochrons that can be directly dated and geochemically fingerprinted, allowing outcrops to be correlated and ages transferred between sequences. The most widespread and well-characterized East African tephra layer of Late Pleistocene age to have been systematically characterized in such a way is the $~ 36$ ka BP Menengai Tuff, found over an area of $>115,000 \mathrm{~km}^{2}$ (Blegen et al., 2016). The use of tephra to date and correlate lacustrine sediment core sequences has been more limited however, due to the paucity of visible tephra layers in some of the region's most important palaeoclimate archives.

A solution, which has been extensively applied across Europe and the North Atlantic region (e.g. Davies et al., 2010; Blockley et al., 2014), is to look for tephra layers that are not visible within their host sediments to the naked eye (termed cryptotephra by Lowe and Hunt (2001)). Cryptotephra investigations open up the possibility to trace airfall tephra layers over far wider distances from their source than visible tephra may be preserved. In doing so, the method increases the number of layers recorded in each sedimentary sequence and introduces the potential to connect archives within extensive regional (and possibly inter-continental) tephrostratigraphic frameworks (e.g. Lowe 
et al., 2015; Lane et al., 2017). Whilst applications beyond the North Atlantic region are still relatively uncommon, the benefits of cryptotephra research are now being realized across eastern Africa. Far-travelled cryptotephra layers have shed light on debates around past climate and human evolution (Lane et al., 2013) as well as providing unique dossiers of explosive volcanism (Martin-Jones et al., 2017a,b) in eastern Africa.

This paper reports on a cryptotephra study from Lake Victoria, which aimed to identify non-visible tephra layers for the first time in this important regional Holocene palaeoenvironmental record. We demonstrate that cryptotephra layers can be located and identified to their source, then use our findings to illustrate the potential contribution that cryptotephra studies will make to palaeoclimate, volcanic hazards and archaeological research in eastern Africa.

\section{Methods}

\subsection{Study site}

Core V95-1P was collected from the northeastern part of Lake Victoria in $1995\left(01^{\circ} 13.9^{\prime} \mathrm{S}\right.$, $33^{\circ} 11.9^{\prime} \mathrm{E}, 68 \mathrm{~m}$ water depth) (Fig. 1), as part of the International Decade of East African Lakes (IDEAL) research programme. The core samples the full Holocene lake sequence and continues back to the Late Pleistocene palaeosol(s). Multi-proxy sedimentary, palaeoenvironmental and palaeoclimatic analyses have documented the changing conditions of the lake, up to recent times (Johnson et al., 2000, Berke et al., 2012).

\subsection{Cryptotephra investigations}

To locate cryptotephra horizons, the full stratigraphy of the V95-1P core sediments was sampled at $10 \mathrm{~cm}$ contiguous and continuous intervals. Glass shards were extracted from the host sediments using the protocol described by Blockley et al. (2005). Dried and weighed sediment samples were sieved to $>25 \mu \mathrm{m}$, and then the $1.95-2.55 \mathrm{~g} / \mathrm{cm}^{3}$ fraction from each sample was isolated using density separation with sodium polytungstate solution. The residues were mounted on glass slides in Canada Balsam and the number of glass shards from each sediment interval was counted using high-power transmitted light microscopy. Tephra glass shard concentrations were calculated as shard per gram of dry sediment (herein $\mathrm{s} / \mathrm{g}$ ) and the down-core shard counts plotted against the site's stratigraphy (Fig. 2). Intervals containing elevated tephra shard concentrations were then sampled at $1-2 \mathrm{~cm}$ resolution (depending on available material) and reprocessed to pinpoint more precisely the depth of each cryptotephra horizon. Shard distributions across a primary cryptotephra deposit in low-energy lacustrine sediments are typically characterized by a sudden peak in shard counts, which attenuates upwards through the stratigraphy (Davies et al., 2012). Isochron positions were identified at $1-2 \mathrm{~cm}$ resolution at the position of the shard peak and each tephra layer given a VT (Victoria Tephra) code based upon its core depth. Additional sediment was sampled from each tephra isochron to extract shards for geochemical characterization. Where shard concentrations suggested prolonged input of ash into the lake, preventing secure designation of an isochron position, multiple samples were selected to test whether the material derived from the same volcanic source.

Major and minor element concentrations of single glass shards in the Victoria tephra layers were determined using a JEOL 8600 wavelength dispersive electron microprobe analyser (WDS-EPMA) at the Research Laboratory for Archaeology and the History of Art (RLAHA, University of Oxford). The glass was analyzed using a defocussed $10 \mu \mathrm{m}$ diameter beam operating at $15 \mathrm{kV}$ and $6 \mathrm{nA}$. Sodium counts were collected over a $10 \mathrm{~s}$ acquisition, $\mathrm{Cl}$ and $\mathrm{P}$ for $60 \mathrm{~s}$ and all other analytes for $30 \mathrm{~s}$. The instrument was calibrated against a suite of mineral and oxide standards, and a range of MPI-DING (Jochum et al., 2005, 2006) glass compositions were analyzed as secondary standards to monitor instrument accuracy and as a means to quantify analytical precision. Due to the variable secondary hydration of glass, all compositional data presented in the text, tables and 
graphs have been normalized to an anhydrous basis. See Supplementary Data file S1 for all raw data, secondary standards and analytical uncertainties.

To identify the volcanic source of a (crypto-) tephra layer, the composition of its glass shards must be matched to a comparable dataset from a securely dated and provenanced proximal eruption unit. Unfortunately, there are limited published data characterising Late Pleistocene to recent tephra erupted from Kenyan Rift volcanoes, and few eruptions have been precisely dated and described.

The works of MacDonald and Scaillet (2006), Marshall et al., (2009) and Clarke et al. (1990) provide a useful overview of central Kenyan Rift volcanism that stands as an important reference on composition and approximate timing of the largest eruptive events. Further whole rock compositional data exists from isolated petrological studies (e.g. Ren et al., 2006) and from tephra layers and obsidians from geologic sources and archaeological sites that pre-date the Lake Victoria sediment record (e.g. Brown et al., 2013; Tryon and McBrearty, 2002). Whilst there are challenges in the comparison of whole rock data, which may incorporate variable quantities of phenocrysts, with tephra glass analyses, as we generated for the Lake Victoria tephra layers, the central Kenyan Rift volcanoes have been shown to erupt distinct compositions (MacDonald and Scaillet, 2006). We therefore compared our results to all available datasets to identify the most likely sources of the Lake Victoria tephra layers.

\subsection{Chronology}

Previous age-models for the V95-1P sediment core (Johnson et al., 2000, Berke et al., 2012) were updated in this study using a Bayesian $P$ _Sequence depositional model in OxCal version 4.3 (Ramsey, 2008, 2009) to allow robust interpolation between age estimates and full calculation of age-model uncertainties. The model uses all eight radiocarbon age measurements previously made on pollen and terrestrial macrofossils from the lacustrine diatomaceous sediments following Berke et al. (2012) and Johnson et al. (2000). Radiocarbon ages made on bulk sediment samples from the palaeosol intervals below $6 \mathrm{~m}$ core depth do not show a coherent increase of age with depth and are not included in the age model.

The $P$ _Sequence model uses a variable K parameter for interpolation between dated horizons (Ramsey and Lee, 2013). In order to derive age-estimates for our cryptotephra layers, isochron positions were input using the Date_function and model interpolated ages reported with 95\% confidence intervals. Radiocarbon ages and full model parameters are detailed in Supplementary Data file S2.

3. Results:

3.1 Cryptotephra stratigraphy

Exploration of the V95-1P core sequence reveals six cryptotephra layers in varying shard concentrations within four discrete intervals of the sediment record (Fig. 2 and Table 1). The lower metre of the V95-1P core contained the highest concentrations of tephra glass shards and four samples were identified for analysis from this interval. Between $\sim 600$ and $\sim 100 \mathrm{~cm}$ depth cryptotephra concentrations do not exceed $1 \mathrm{~s} / \mathrm{g}$, however shards reappear in uppermost metre and two further horizons were studied across this interval. Each cryptotephra-bearing interval is described here, beginning with the deepest (=oldest) layer and working upwards.

\section{Cryptotephra layers VT683 \& VT675: 690-670 cm depth}

Tephra glass shards reach concentrations of $>1000 \mathrm{~s} / \mathrm{g}$ in the basal $20 \mathrm{~cm}$ of the sediments that were studied, with the exception of lower shard concentrations $(663 \mathrm{~s} / \mathrm{g}$ ) (between $681-680 \mathrm{~cm}$ depth (Fig 2). The two samples with the highest concentrations across this $690-670 \mathrm{~cm}$ depth interval, identified here as VT683 (2800 s/g) and VT675 (3362 s/g) were prepared for compositional analyses to see if the tephra above and below the reduction in shard counts are 
derived from the same volcanic episode. Both horizons contain clear shards of pumiceous, platy and bubble wall morphologies and ranging in size from 50-150 $\mu \mathrm{m}$ (measured along the longest axis length).

\section{Cryptotephra layers VT644 \& VT636: $644-624 \mathrm{~cm}$ depth}

A $50 \mathrm{~cm}$ interval from $644-624 \mathrm{~cm}$ depth contains the highest concentrations of glass shards seen throughout the Victoria archive (Fig 2). Two cryptotephra horizons are defined; VT644 at 644-640 $\mathrm{cm}$ depth, with concentrations of $>80,000 \mathrm{~s} / \mathrm{g}$, and another, VT636, with a peak of $>60,000 \mathrm{~s} / \mathrm{g}$ at $636 \mathrm{~cm}$ depth showing decreasing concentrations upward to $624 \mathrm{~cm}$ depth. Cryptotephra layers VT644 and VT636 contain transparent pumiceous, vesicular and bubble wall shards (Fig. 3). Glass shards in these horizons are the coarsest $(50-400 \mu \mathrm{m})$ amongst the Victoria cryptotephras. These two high shard concentration layers are separated by four centimetres of sediment containing notably lower concentrations of glass, potentially suggesting on-going but variable deposition from a prolonged phase of volcanism.

\section{Cryptotephra layer VT80: $84-78 \mathrm{~cm}$ depth}

Cryptotephra VT80 occurs at $82-79 \mathrm{~cm}$ depth, and is the first appearance of shards following the $\sim 600-100 \mathrm{~cm}$ interval of the Victoria sediments in which cryptotephra layers were not recorded $(<1$ $\mathrm{s} / \mathrm{g}$ ). The horizon contains extremely low shard concentrations of $40 \mathrm{~s} / \mathrm{g}$, represented by clear, platy, bubble-wall shards of $<100 \mu \mathrm{m}$ in size.

\section{Cryptotephra layer VT22: 22-10 cm depth}

The uppermost cryptotephra layer (VT22) is located at $22 \mathrm{~cm}$ depth, and contains $\sim 12,000 \mathrm{~s} / \mathrm{g}$ (Fig 2). The shards in VT22 vary in morphology from bubble wall, platy to pumiceous shards and vary in size from $50-100 \mu \mathrm{m}$.

\subsection{Glass shard chemistry}

The composition of glass shards in the six samples from the V95-1P cryptotephra horizons is summarized in Table 1 and Figure 4. Full compositional data are presented in Supplementary Data file S1. All cryptotephra layers are peralkaline rhyolites, defined by two distinct compositional populations. Excluding a single pantelleritic outlier, glass shards in the four oldest cryptotephra samples VT683, VT675; VT644 and VT636 contain 72.17-75.91 wt. \% $\mathrm{SiO}_{2}, 9.67-11.07$ wt. \% $\mathrm{Al}_{2} \mathrm{O}_{3}$ and 3.11-3.70 wt.\% $\mathrm{FeO}^{\top}$ and can be classified as comendites. Glass shards in the two youngest cryptotephra layers VT80 and VT22 have pantelleritic compositions and contain lower $\mathrm{SiO}_{2}$ (72.44-73.2 wt. \%) and $\mathrm{Al}_{2} \mathrm{O}_{3}$ (8.17-8.45 wt. \%) and higher $\mathrm{FeO}^{\top}$ (6.18-6.68 wt. \%) concentrations than older Victoria cryptotephras. The comenditic and pantelleritic tephra layers have eutectic glass compositions and cannot be clearly distinguished relative to other members of each group.

Due to their proximity in depth and indistinguishable major and minor element compositions, we are unable to prove with certainty whether the two lower pairs of cryptotephra layers, VT683 / VT675 and VT644 / VT636, each represent two eruptions within an extended period of volcanic activity, or intervals of reworking / delayed input of tephra within the lake-catchment system.

\subsection{Modelled tephra ages}

The updated Bayesian age-depth model for V95-1P shows approximately stable sedimentation rates (Fig. 5) throughout the $625 \mathrm{~m}$ diatomaceous mud unit, with age uncertainties at $95 \%$ confidence intervals varying from 350-990 years in this upper part. No age model was run below $625 \mathrm{~m}$, where radiocarbon dates from the sandy-palaeosol units show inconsistent age-depth 
relationships. Consequently, only a minimum age estimate of $>15,000$ cal years BP can be made for the lower tephra layers: VT636, VT644, VT675 and VT683.

All tephra age-estimates are given in Table 2. Tephra layers VT80 and VT22 are dated to 3151 2537 cal yrs BP and 1973-1395 cal yrs BP respectively, representing two separate tephra depositional events that occurred in the late Holocene. A hiatus in tephra deposition lasted at least 12,000 years, prior to the eruption of VT80, suggestive of either an extended period of volcanic quiescence, reduced erupted ash volumes and/or changes in the atmospheric dispersal patterns of ash from eruptions in the nearby central Kenyan Rift.

\section{Discussion}

4.1 The volcanic sources of the Lake Victoria tephras

Figure 4 compares the glass composition of the Lake Victoria cryptotephra layers with published whole rock and obsidian data on samples from nearby central Kenyan Rift volcanoes. These comparisons should be made with caution, as whole rock analyses can contain variable quantities of phenocrysts, whilst glass (e.g. tephra shards and obsidian) analyses represent the magma composition at the time of the eruption. Aeolian fractionation processes may create compositional differences between samples from the same eruption by preferential removal of the densest (more basic) material and extended transport of the lightest (more evolved) material to the most distal localities. Typically, therefore, glass compositions appear more evolved than whole rock data and the latter may contain greater internal variability depending upon distance and direction of the sample from its eruptive source. Similarly, individual tephra samples and obsidians may show restricted compositions if they sample only part of an evolving magma composition from a particular phase of an eruption. Nonetheless, Kenyan Rift volcanoes erupt characteristically distinctive compositions in terms of their major elements (Fig. 4, MacDonald and Scaillet, 2006) and we exploit these geochemical signatures to test the potential sources of the Victoria cryptotephras here.

Five central Kenyan Rift volcanoes are known to have been active through the Quaternary-Recent. Menengai, Longonot and Suswa erupt trachytes and phonolites, whilst Eburru and Olkaria erupt trachytes and rhyolites (MacDonald and Scaillet, 2006; Fig. 4). Eburru and Olkaria are thus the only known Kenyan volcanoes to erupt peralkaline rhyolitic compositions

Glass shards in the Victoria tephra layers are comenditic to pantelleritic rhyolites - compositions erupted only from the Eburru and Olkaria volcanoes. The composition of glass shards in the four oldest Victoria tephra layers (VT683, VT675, VT644 and VT636) matches that of whole rock analyses from tuffs erupted from Olkaria and show a good affinity with Olkaria obsidian data (Marshall et al., 2009; Brown et al., 2013). A small compositional off-set between obsidian compositions related to Olkaria (Brown et al., 2013) and our distal tephra samples (Fig. 4), could be explained by analytical procedural differences, or compositional differences between different Olkaria eruptives, however it may merely represent sampling of material from a more distal location.

Previously published ages for eruptions of Olkaria are poorly constrained, being estimated only relative to closely-associated, dated, lava flows, tuffs and / or geomorphological features (MacDonald and Scaillet, 2009; Clarke et al. 1990). Four chronologically distinct volcanic episodes have previously been defined by Clark et al., 1990, occurring between 21 ka BP and the present. The oldest of these was an explosive phase dated to $<21 \mathrm{ka}$ and represented by the Olkaria Lower Comendite (OLC), found in outcrop close to Lake Naivasha. The OLC age is poorly constrained, being based on its stratigraphic relationship to tephra layers from Longonot, which are in turn dated relative to regional lake highstand events $\sim 21 \mathrm{ka} \mathrm{BP}$ (Clarke et al., 1990). Three younger effusive 
phases are dated to $~ 9 \mathrm{ka}$ (the Olkaria Middle Comendite), $6 \mathrm{ka}$ (the Olkaria Lower Comendite) and $\sim 180$ a BP (the Ololbutot Comendite) (Clarke et al. 1990). Our discovery of far travelled tephra from Olkaria in Lake Victoria's sediments pre-dating $15 \mathrm{ka} \mathrm{BP}$, most likely represents distal ashfall related to the earliest OLC explosive phase. Tentatively we therefore correlate VT636/VT644, which show the highest tephra shard concentrations in the Lake Victoria record, to this event. However, the record also appears to also capture an older, unknown Olkaria event in the lowermost tephra layers (VT675/VT683). There is growing evidence for earlier comenditic rhyolite eruptions of Olkaria, for example, Blegen et al (2015) describe a vitric ash, chemically correlated to Olkaria, pre-dating the 49 ka BP Nyamita tuff at the Kisaaka, Karungu locality, on the shores of modern Lake Victoria. Merrick et al (1994) also described obsidians of Olkaria composition, within Middle Stone Age archaeological sites and dating to $>50 \mathrm{ka} \mathrm{BP}$. It seems likely that a longer lake sediment core stratigraphy and further information from the proximal volcanic record would reveal a much extended eruptive history for Olkaria volcano.

Glass shards in the two youngest Victoria tephra layers (VT80 and VT22) bear an affinity to pantelleritic eruptives from Eburru, which contain lower $\mathrm{SiO}_{2}, \mathrm{Al}_{2} \mathrm{O}_{3}$ and higher $\mathrm{FeO}^{\top}$ concentrations than Olkaria whole rock and obsidian analyses (Fig. 4, Ren et al., 2006; Brown et al., 2013). The glass shards in VT22 and VT80 appear marginally more evolved than Eburru whole rock and obsidian compositions, showing $\sim 1 \%$ higher $\mathrm{SiO}_{2}$ concentrations and $\sim 1 \mathrm{wt} . \%$ less $\mathrm{FeO}^{\top}$ than the most evolved proximal Eburru samples (Fig. 4). Once again, these differences are likely due to aeolian fractionation, reinforcing the concept that direct comparisons cannot always be made between different types of data and ideally proximal airfall ash from the same eruption would be available for direct comparison.

In summary, the V95-1P sediment core records prolonged or repeated comenditic eruptions from Olkaria occurring prior to $15 \mathrm{ka}$ and two more recent, previously unrecorded pantelleritic eruptions from Eburru 3.8-1.2 ka. These cryptotephra layers are recorded $>300 \mathrm{~km}$ from their respective source volcanoes (Fig. 1), illustrating that these eruptions were of sufficient magnitude to widely disperse fine-grained volcanic ash.

\subsection{Toward a cryptotephra stratigraphy for eastern Africa}

This is the first time that cryptotephra layers have been identified in the sediments of Lake Victoria, despite many decades of research on sediment cores from this iconic lake. Their correlation to Eburru and Olkaria volcanoes in the central Kenyan Rift, some $300 \mathrm{~km}$ away implies that these were voluminous eruption events and airfall-derived ash from these eruptions will most likely be identifiable as cryptic, or potentially visible layers, in other Late Pleistocene to Holocene lake sediment cores from the region. These horizons may in the future be established as isochrons that could provide precise tie-lines between palaeoclimate archives, facilitating robust comparison of environmental conditions over 100's of km distances in eastern Africa. It is interesting to note that the Olkaria tephra appear toward the top of the sandy-palaeosol units and thus predate the establishment of permanent lacustrine conditions (Fig. 2). Whilst in a subaerial environment tephra may be subject to weathering and reworking processes, the excellent tephra preservation and definition of the larger peaks in shard concentration indicate limited exposure. These layers in particular may provide potentially informative basin-wide as well as regional markers during a time of significant regional hydrological change.

\subsection{Wider potential for multidisciplinary applications}

The recent volcanic history for the Kenyan Rift remains poorly constrained (Siebert et al., 2010) however the Lake Victoria tephra-record shows that both Eburru and Olkaria have erupted 
explosively during the recent past. Our new cryptotephra correlations document and date Late Holocene explosive eruptions from Eburru for the first time. We also provide minimum ages that further constrain the timing of the last explosive eruption phase from Olkaria, represented in outcrop by the Olkaria Lower Comendites (Clark et al., 1990) and add to the growing evidence that Olkaria has been active for much longer than previously thought (e.g. Blegen et al., 2015). Further lake sediment tephra records could provide an effective means to document in detail the explosive eruptive history of central Kenyan volcanoes, as has been done for other regions of eastern Africa (Martin-Jones et al., 2017a,b). Future explosive eruptions from the central Kenyan Rift volcanoes could present a threat to the population of Nairobi, located only $\sim 80 \mathrm{~km}$ away, therefore robust eruption frequency information is important for our understanding of ash-fall hazards from littlestudied volcanic centres.

Our Holocene record demonstrates that there is significant potential to develop a complete tephrostratigraphy for the Lake Victoria basin over longer time scales. Until now, much tephra research in eastern Africa has focused on the Pliocene to Middle Pleistocene palaeoanthropological sites (e.g. Feibel et al., 1999; Wolde-Gabriel et al., 2005; Tryon and McBrearty, 2006). Blegen et al. (2015) recently compiled a regional Late Pleistocene tephra framework for the Lake Victoria basin, and identified at least eight distinct eruptions across this interval, of which four produced widespread ash layers. This important work provides a first framework for the correlation and dating of anthropological sites during intervals crucial for modern human evolution and dispersal out of Africa. Extending this tephrostratigraphy to include palaeoenvironmental archives from regional lakes, such as from Lake Victoria, will tie human histories directly into nearby records of climate change.

\section{Conclusions}

Studying the rates and nature of past environmental changes is especially relevant in climatically sensitive regions such as eastern Africa, and underpinning these interpretations with high resolution chronology is paramount. In this paper we have highlighted the potential for using cryptotephra methodologies to build an event-stratigraphic framework for sediment sequences along the East African Rift. We have identified far-travelled ash-fall from two phases of explosive eruptive activity from Olkaria and Eburru volcanoes that may provide important markers for post LGM palaeoenvironmental and palaeohydrological evolution across the region.

Future work utilising similar approaches in nearby lake and archaeological sequences will extend the reach of a fledging regional tephrostratigraphy both in space and time. As tephra glass shard compositional datasets grow, challenges of correlating distal tephra layers will decrease. Studies of proximal outcrops, with complementary ash-fall glass analyses are needed to secure correlations of distal tephra to their volcanic source. This work therefore demands cooperation and data sharing between volcanologists, tephrochronologists and archaeologists, all of whom will benefit from a better understanding of the timing and impacts of explosive volcanism through the recent past.

\section{Acknowledgements}

The authors would like to recognize the contribution of Freiderike Murach-Ward for her assistance in processing laboratory samples, Dr. Nick Blegen for valuable discussions about central Kenyan tephra and Dr. Victoria Smith for support with EPMA. We also thank Anders Noren, Kristina Brady and the staff at LacCore, University of Minnesota, for their assistance accessing and sub-sampling the V95-1P sediment cores. Cryptotephra research was funded as part of a Leverhulme Trust Early Career Fellowship to CL. 


\section{Figures:}

Fig. 1. Map showing the location of Lake Victoria in eastern Africa. The location of core V95-1P is indicated with a star. Volcanoes with suspected Holocene activity are marked by triangles (Eburru and Olkaria in orange), with those referred to in the text labelled.

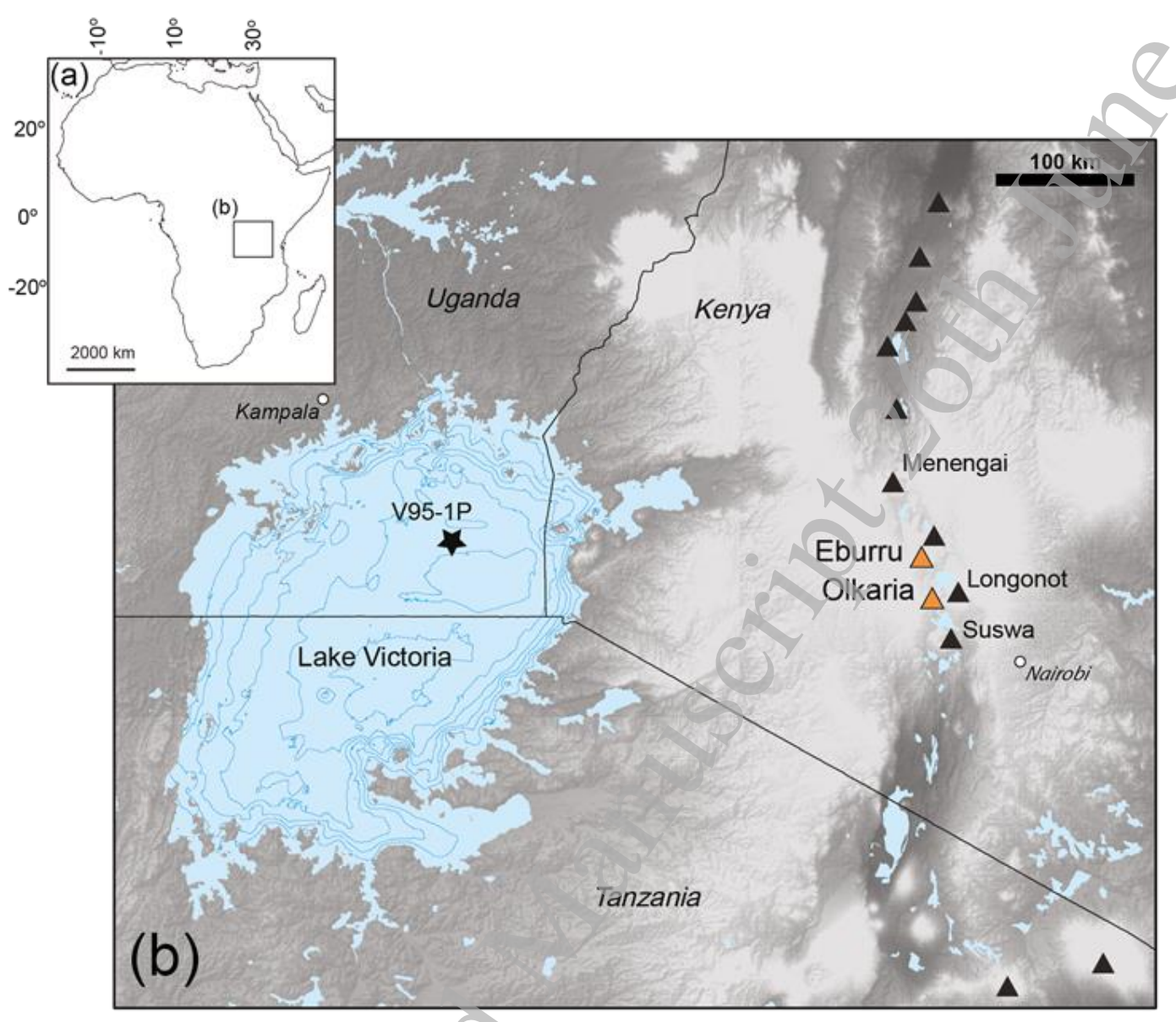


Fig. 2. Distribution of cryptotephra glass shards within the V95-1P sediment record. Left panel shows a whole core overview, alongside sediment core stratigraphy following Berke et al. (2012). Blow-outs A-D show shard distributions in detail for all tephra horizons, with shaded bars indicating the six samples analysed within this study.

Tephra glass shards / gram
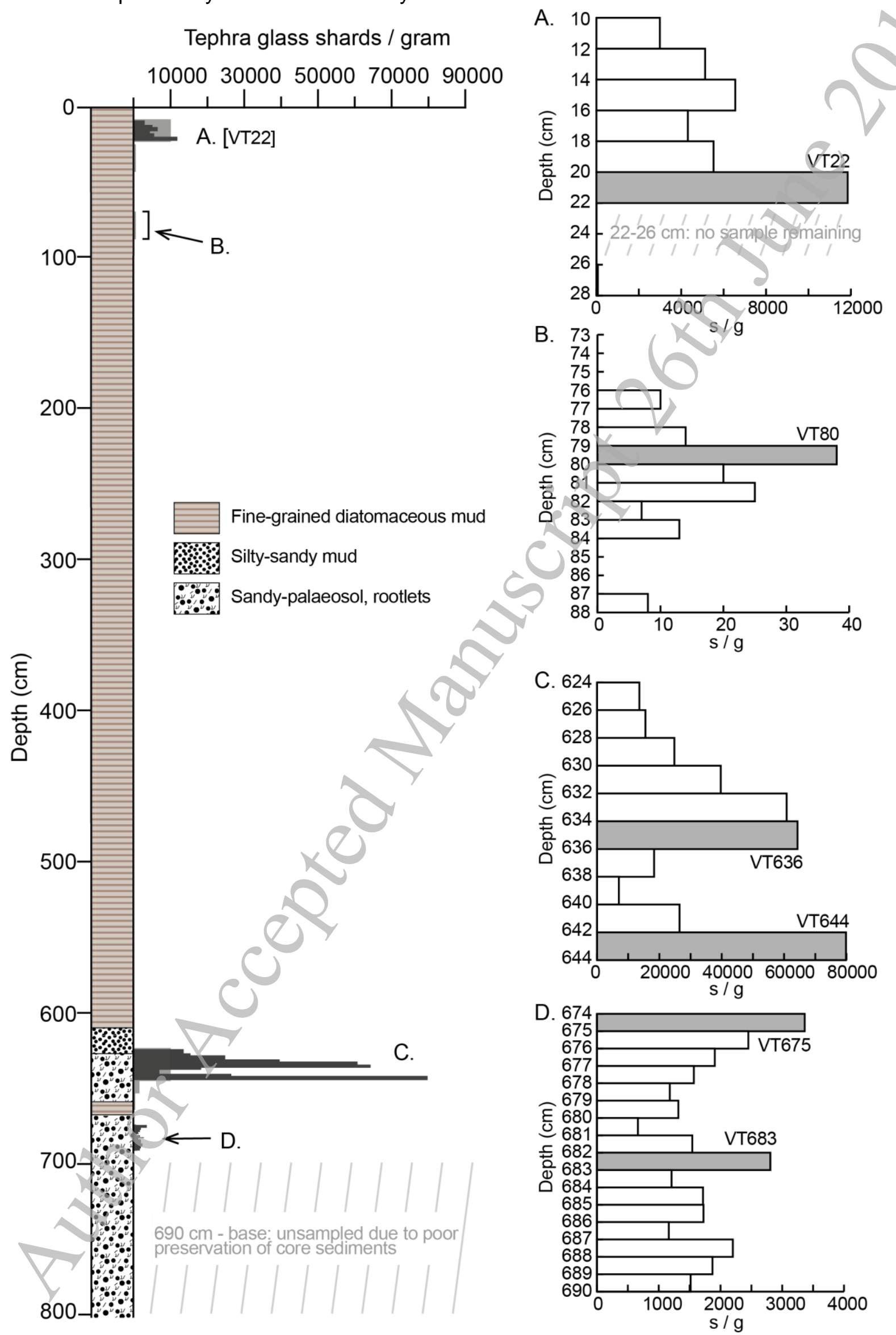
Fig. 3. Transmitted light photomicrographs of glass shards in the Lake Victoria cryptotephra layers (a) VT22, (b) VT675, (c) VT683, (d) VT636 and (e) VT644. (f) Outline drawings of selected glass shards illustrating typical pumiceous, vesicular, bubble wall and platy morphologies observed in the Lake Victoria cryptotephra layers. The cryptotephra layers contain transparent, pristine shards that range in size from 50-150 $\mu \mathrm{m}$, however VT636 and VT644 contain grains of up to $400 \mu \mathrm{m}$.
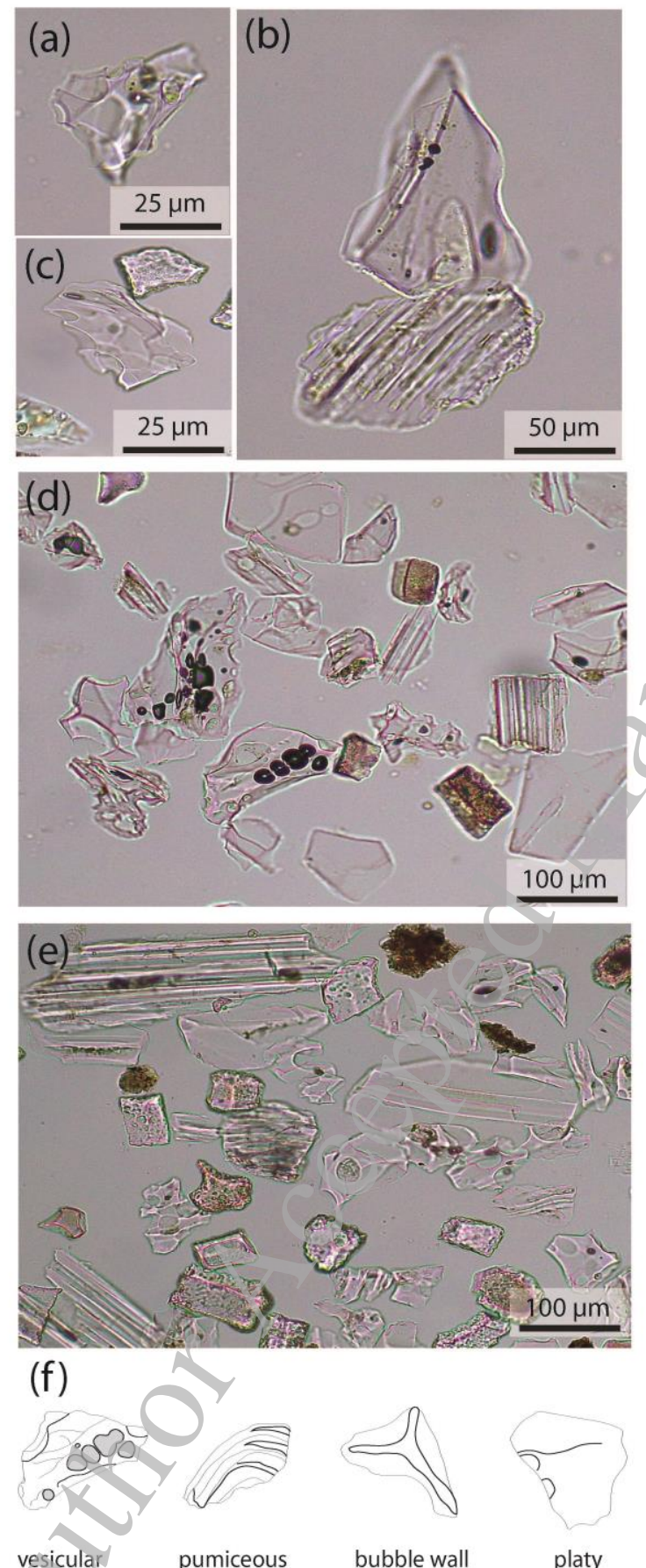

$$
\text { vesicular pumiceous bubble wall platy }
$$


Fig. 4. Major element composition (wt. \%) of single glass shards in the Lake Victoria cryptotephra layers, plotted alongside whole rock and obsidian glass analyses for the Olkaria and Eburru volcanoes (Ren et al., 2006; Marshall et al., 2009; Brown et al., 2013), with whole rock compositional envelopes for major volcanic centres in the Kenyan Rift adapted from MacDonald and Scaillet (2006). A) Total alkali silica diagram, showing that the Victoria cryptotephra glass shards are rhyolitic and their composition matches eruptives from Eburru and Olkaria, which are the only Kenyan Rift centres to erupt peralkaline rhyolites. B) and C) Bi-plots showing concentrations of $\mathrm{FeO}^{\top}$ and $\mathrm{SiO}_{2}$ versus $\mathrm{Al}_{2} \mathrm{O}_{3}$ in the Victoria cryptotephra shards. The four oldest cryptotephra layers (VT636, VT644, VT675 and VT683) are comenditic $\mathrm{Al}_{2} \mathrm{O}_{3}>1.33\left(\mathrm{FeO}^{\top}+4\right)(\mathrm{Le}$ Maitre, 2002) and their glass composition correlates to published data on Olkaria. The two youngest horizons (VT22 and VT80) contain pantelleritic $\mathrm{Al}_{2} \mathrm{O}_{3}<1.33\left(\mathrm{FeO}^{\top}+4\right)$ glass shards which have similar compositions to eruptives from Eburru. All data normalized to water-free (100 wt. \%) prior to plotting. Raw analytical data can be found in Supplementary Data file S1. 

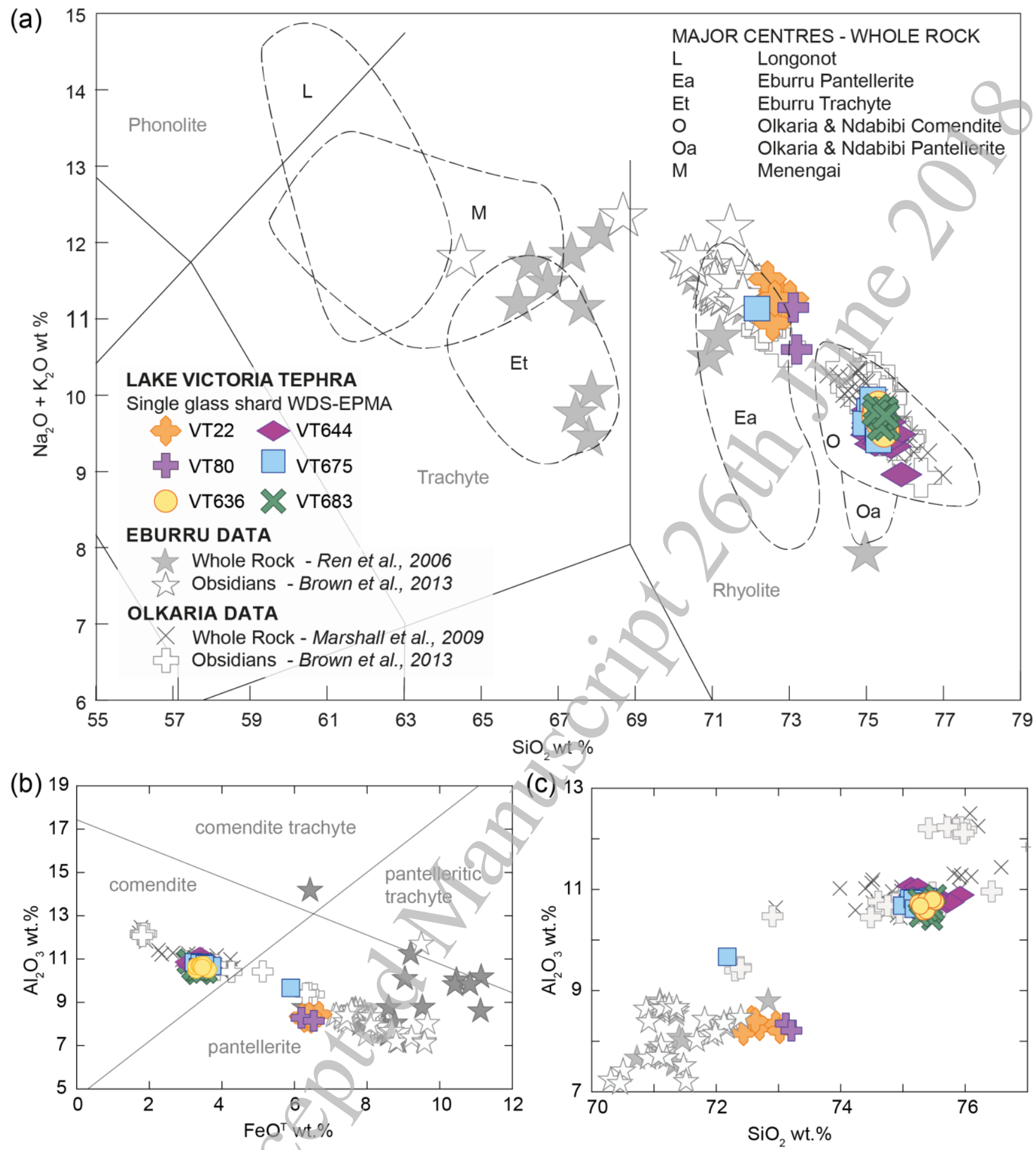
Fig. 5. Age-depth model for VP95-1P, showing constraints of cryptotephra ages (in blue). Bayesian $P$ _Sequence deposition model for the upper lake sediment record $(0--625 \mathrm{~cm})$ run in OxCal version 4.3 (Ramsey et al., 2008, 2009). Probability distributions and interpolated age-depth model (in green) plotted with $95 \%$ confidence intervals. Radiocarbon dates within the lower paleosol horizons (below $625 \mathrm{~cm}$ ) are calibrated using IntCal13 (Reimer et al., 2013) but not included in the depositional model due to the significant scatter in measured ages. Full model parameters and references given in Methods and Supplementary Data file S2.

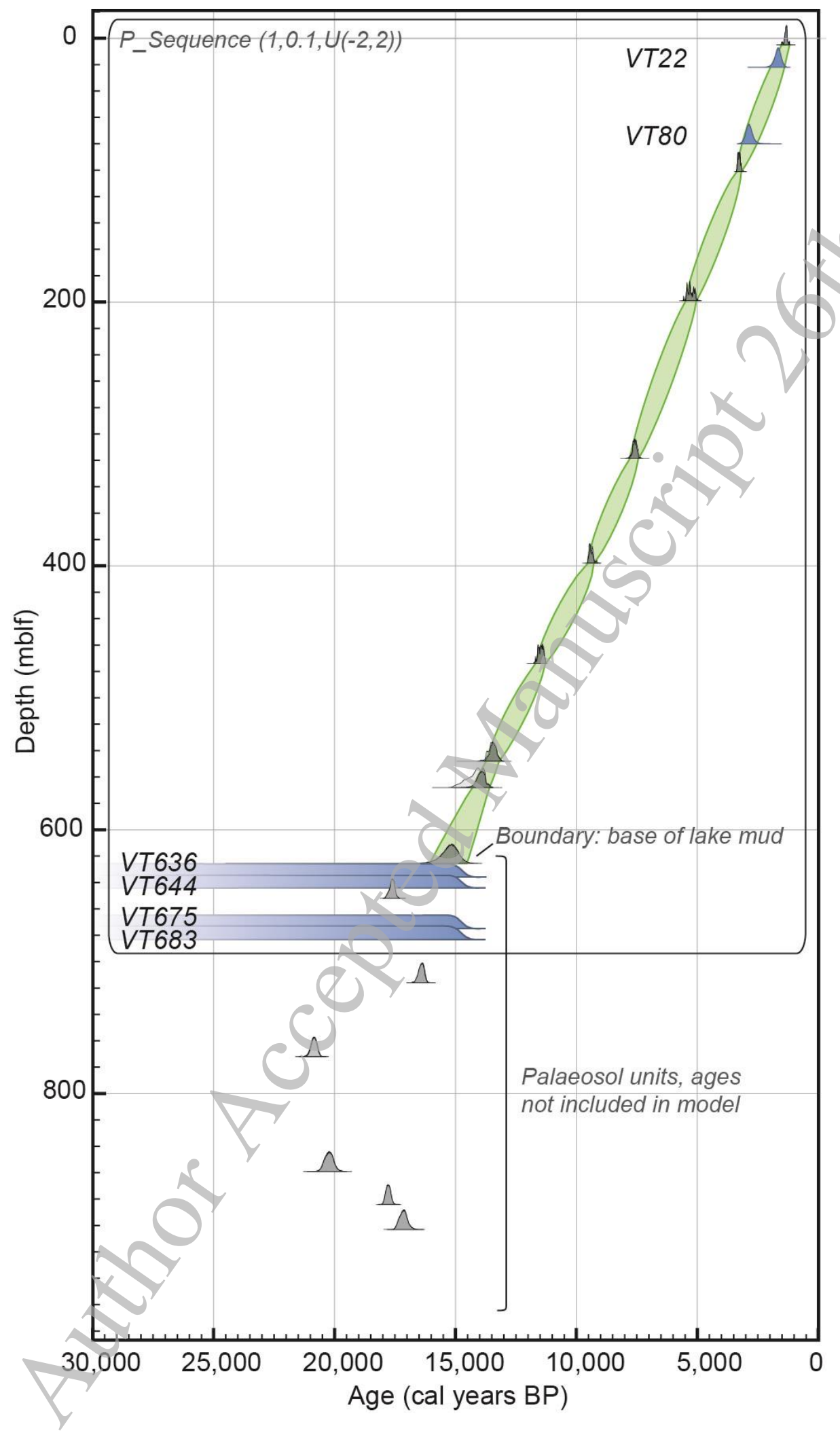


Tables:

Table 1. Averages and $2 \sigma$ ranges for normalized major element composition (wt. \%) of glass shards in each of the Lake Victoria cryptotephra layers. For the full geochemical dataset, see Supplementary Data file S1 (Table S2).

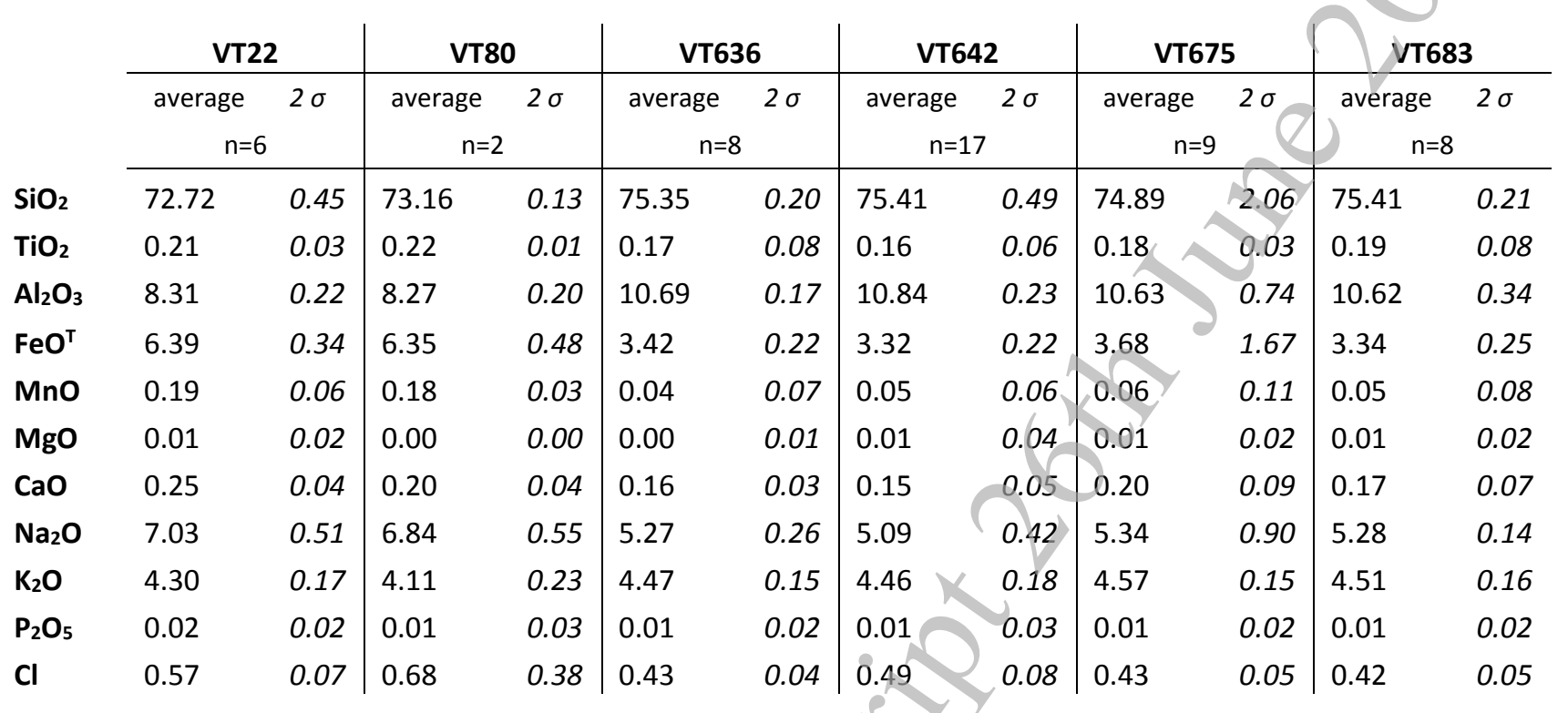

Table 2. Summary of modelled ages (quoted with $95 \%$ confidence intervals) and correlations for all six V95-1P cryptotephra samples.

\begin{tabular}{llll}
\hline $\begin{array}{l}\text { Tephra } \\
\text { sample }\end{array}$ & $\begin{array}{l}\text { Core depth } \\
(\mathbf{c m})\end{array}$ & $\begin{array}{l}\text { Source } \\
\text { volcano }\end{array}$ & $\begin{array}{l}\text { Modelled age } \\
\text { (yrs BP, 95,4\% CL) }\end{array}$ \\
\hline VT22 & 22 & Eburru & $1973-1395$ \\
VT80 & 80 & Eburru & $3151-2537$ \\
VT636 & 636 & Olkaria & $>15,000$ \\
VT644 & 644 & Olkaria & $>15,000$ \\
VT675 & 675 & Olkaria & $>15,000$ \\
VT683 & 683 & Olkaria & $>15,000$ \\
\hline
\end{tabular}

\section{References}

Berke, M. A., T. C. Johnson, J. P. Werne, K. Grice, S. Schouten, and J. S. S. Damsté. 2012. Molecular records of climate variability and vegetation response since the Late Pleistocene in the Lake Victoria basin, East Africa. Quaternary Science Reviews 55:59-74.

Beuning, K. R., K. Kelts, J. Russell, and B. B. Wolfe. 2002. Reassessment of Lake Victoria-Upper Nile River paleohydrology from oxygen isotope records of lake-sediment cellulose. Geology 30:559-562.

Blegen, N., C. A. Tryon, J. T. Faith, D. J. Peppe, E. J. Beverly, B. Li, and Z. Jacobs. 2015. Distal tephras of the eastern Lake Victoria basin, equatorial East Africa: correlations, chronology and a context for early modern humans. Quaternary Science Reviews 122:89-111.

Blegen, N., F. H. Brown, B. R. Jicha, K. M. Binetti, J. T. Faith, J. V. Ferraro, P. N. Gathogo, J. L. Richardson, and C. A. Tryon. 2016. The Menengai Tuff: A 36 ka widespread tephra and its chronological relevance to Late Pleistocene human evolution in East Africa. Quaternary Science Reviews 152:152- 
168.

Blockley, S., S. Pyne-O'Donnell, J. Lowe, I. Matthews, A. Stone, A. Pollard, C. Turney, and E. Molyneux. 2005. A new and less destructive laboratory procedure for the physical separation of distal glass tephra shards from sediments. Quaternary Science Reviews 24:1952-1960.

Blockley, S. P. E., A. J. Bourne, A. Brauer, S. M. Davies, M. Hardiman, P. R. Harding, C. S. Lane, A. MacLeod, I. P. Matthews, S. D. F. Pyne-O'Donnell, S. O. Rasmussen, S. Wulf, and G. Zanchetta. 2014. Tephrochronology and the extended intimate (integration of ice-core, marine and terrestrial records) event stratigraphy 8-128 ka b2k. Quaternary Science Reviews 106:88-100.

Brown, F.H. and Fuller, C.R., 2008. Stratigraphy and tephra of the Kibish Formation, southwestern Ethiopia. Journal of Human Evolution, 55:366-403.Brown, F., B. Nash, D. Fernandez, H. Merrick, and R. Thomas. 2013. Geochemical composition of source obsidians from Kenya. Journal of Archaeological Science 40:3233-3251.

Clarke, M., D. Woodhall, D. Allen, and G. Darling. 1990. Geological, volcanological and hydrogeological controls on the occurrence of geothermal activity surrounding Lake Naivasha, Kenya. Republic of Kenya, Ministry of Energy.

Davies, S. M., P. M. Abbott, N. J. Pearce, S. Wastegård, and S. P. Blockley. 2012. Integrating the INTIMATE records using tephrochronology: rising to the challenge. Quaternary Science Reviews 36:11-27.

Davies, S. M., S. Wastegård, P. Abbott, C. Barbante, M. Bigler, S. J Johnsen, T. L. Rasmussen, J. P. Steffensen, and A. Svensson. 2010. Tracing volcanic events in the NGRIP ice-core and synchronising North Atlantic marine records during the last glacial period. Earth and Planetary Science Letters 294:69-79.

Feibel, C. S. 1999. Tephrostratigraphy and geological context in paleoanthropology. Evolutionary Anthropology: Issues, News, and Reviews 8:87-100.

Jochum, K. P., U. Nohl, K. Herwig, E. Lammel, B. Stoll, and A. W. Hofmann. 2005. GeoReM: a new geochemical database for reference materials and isotopic standards. Geostandards and Geoanalytical Research 29:333-338.

Jochum, K. P., B. Stoll, K. Herwig, M. Willbold, A. W. Hofmann, M. Amini, S. Aarburg, W. Abouchami, E. Hellebrand, and B. Mocek. 2006. MPI-DING reference glasses for in situ microanalysis: New reference values for element concentrations and isotope ratios. Geochemistry, Geophysics, Geosystems 7.

Johnson, T. C., K. Kelts, and E. Odada. 2000. The holocene history of Lake Victoria. AMBIO: A Journal of the Human Environment 29:2-11.

Johnson, T. C., C. A. Scholz, M. R. Jalbot, K. Kelts, R. Ricketts, G. Ngobi, K. Beuning, I. Ssemmanda, and J. McGill. 1996. Late Pleistocene desiccation of Lake Victoria and rapid evolution of cichlid fishes. Science 273:1091-1093.

Kendall, R. L. 1969. An ecological history of the Lake Victoria basin. Ecological Monographs 39:121-176.

Lane, C. S., B. T. Chorn, and T. C. Johnson. 2013. Ash from the Toba supereruption in Lake Malawi shows no volcanic winter in East Africa at $75 \mathrm{ka}$. Proceedings of the National Academy of Sciences 110:8025-8029.

Lane, C. S., D. J. Lowe, S. Blockley, T. Suzuki, and V. Smith. 2017. Advancing tephrochronology as a global dating tool: Applications in volcanology, archaeology, and palaeoclimatic research. Elsevier.

Le Maitre, R, A. Streckeisen, B. Zanettin, M. Le Bas, B. Bonin, P. Bateman, G. Bellieni, A. Dudek, S. Efremova, and J. Keller. 2002. Igneous Rocks: A Classification and Glossary of Terms: A Classification and Glossary of Terms: Recommendations of the International Union of Geological Sciences, Subcommission on the Systematics of Igneous Rocks. Cambridge University Press UK.

Lowe, D. J., and J. B. Hunt. 2001. A summary of terminology used in tephra-related studies. Les Dossiers de l'Archaéo-Logis 1. 
Lowe, J. J., C. B. Ramsey, R. A. Housley, C. S. Lane, E. L. Tomlinson, R. Associates, and R. Team. 2015. The RESET project: constructing a European tephra lattice for refined synchronisation of environmental and archaeological events during the last c. 100 ka. Quaternary Science Reviews 118:1-17.

Macdonald, R., and B. Scaillet. 2006. The central Kenya peralkaline province: insights into the evolution of peralkaline salic magmas. Lithos 91:59-73.

Marshall, A., R. Macdonald, N. Rogers, J. Fitton, A. Tindle, K. Nejbert, and R. Hinton. 2009. Fractionation of peralkaline silicic magmas: The greater olkaria volcanic complex, Kenya Rift Valley. Journal of Petrology 50:323-359.

Martin-Jones, C. M., C. S. Lane, N. Pearce, V. C. Smith, H. Lamb, C. Oppenheimer, A. Asrat, and F. Schaebitz. 2017. Glass compositions and tempo of post-17 ka eruptions from the Afar Triangle recorded in sediments from lakes Ashenge and Hayk, Ethiopia. Quaternary Geochronology 37:1531.

Martin-Jones, C. M., C. S. Lane, N. J. Pearce, V. C. Smith, H. F. Lamb, F. Schaebitz, F. Viehberg, M. C. Brown, U. Frank, and A. Asrat. 2017. Recurrent explosive eruptions from a high-risk Main Ethiopian Rift volcano throughout the Holocene. Geology 45:1127-1130.

Merrick, H.V., Brown, F.H., Nash, W.P., 1994. Use and movement of obsidian in the Early and Middle Stone Ages of Kenya and northern Tanzania, in: Childs, S.T. (Ed.), Society, Culture, and Technology in Africa. MASCA, pp. 29-44.

Ramsey, C. B. 2008. Deposition models for chronological records. Quaternary Science Reviews 27:42-60.

Ramsey, C. B. 2009. Bayesian analysis of radiocarbon dates. Radiocarbon 51:337-360.

Ramsey, C. B., and S. Lee. 2013. Recent and planned developments of the program OxCal. Radiocarbon 55:720-730.

Reimer, P. J., E. Bard, A. Bayliss, J. W. Beck, P. G. Blackwell, C. B. Ramsey, C. E. Buck, H. Cheng, R. L. Edwards, and M. Friedrich. 2013. IntCal13 and Marine13 radiocarbon age calibration curves 050,000 years cal BP. Radiocarbon 55:1869-1887.

Ren, M., P. A. Omenda, E. Y. Anthony, J. C. White, R. Macdonald, and D. Bailey. 2006. Application of the QUILF thermobarometer to the peralkaline trachytes and pantellerites of the Eburru volcanic complex, East African Rift, Kenya. Lithos 91:109-124.

Scholz, C., T. Johnson, P. Cattaneo, H. Malinga, and S. Shana. 1998. Initial results of 1995 IDEAL seismic reflection survey of Lake Victoria, Uganda and Tanzania. Pages 47-57 Environmental change and response in East African lakes. Springer.

Siebert, L., T. Simkin, and P. Kimberly. 2010. Volcanoes of the world, third edn. Smithsonian Institution. University of California Press, Berkeley, CA.

Stager, J. C. 1984. The diatom record of Lake Victoria (East Africa): the last 17, 000 years. In Proceedings of the seventh international diatom symposium: 455-476.

Stager, J.C., Cumming, B. and Meeker, L., 1997. A high-resolution 11,400-yr diatom record from Lake Victoria, East Africa. Quaternary Research 47: 81-89.

Stager, J., and T. Johnson. 2008. The late Pleistocene desiccation of Lake Victoria and the origin of its endemic biota. Hydrobiologia 596:5-16.Talbot, M. R., and T. Lærdal. 2000. The Late PleistoceneHolocene palaeolimnology of Lake Victoria, East Africa, based upon elemental and isotopic analyses of sedimentary organic matter. Journal of Paleolimnology 23:141-164.

Tryon, C. A., S. McBrearty, and P.-J. Texier. 2005. Levallois lithic technology from the Kapthurin formation, Kenya: Acheulian origin and Middle Stone Age diversity. African Archaeological Review 22:199-229.

Tryon, C.A., Faith, J.T., Peppe, D.J., Beverly, E.J., Blegen, N., Blumenthal, S.A., Chritz, K.L., Driese, S.G., Patterson, D. and Sharp, W.D. 2016. The Pleistocene prehistory of the Lake Victoria 
basin. Quaternary International, 404: 100-114.

Verheyen, E., Salzburger, W., Snoeks, J. and Meyer, A. 2003. Origin of the superflock of cichlid fishes from Lake Victoria, East Africa. Science, 300 (5617): 325-329.

Verschuren, D., T. C. Johnson, H. J. Kling, D. N. Edgington, P. R. Leavitt, E. T. Brown, M. R. Talbot, and R. E. Hecky. 2002. History and timing of human impact on Lake Victoria, East Africa. Proceedings of the Royal Society of London B: Biological Sciences 269:289-294.

WoldeGabriel, G., W. K. Hart, S. Katoh, Y. Beyene, and G. Suwa. 2005. Correlation of Plio-Pleistocene Tephra in Ethiopian and Kenyan rift basins: Temporal calibration of geological features and hominid fossil records. Journal of Volcanology and Geothermal Research 147:81-108. 


\section{Supplementary Data file 1}

Table S1 Major and minor element wt. \% oxide compositions of individual tephra glass shards in each of the Lake Victoria V95-1P cryptotephra layers.

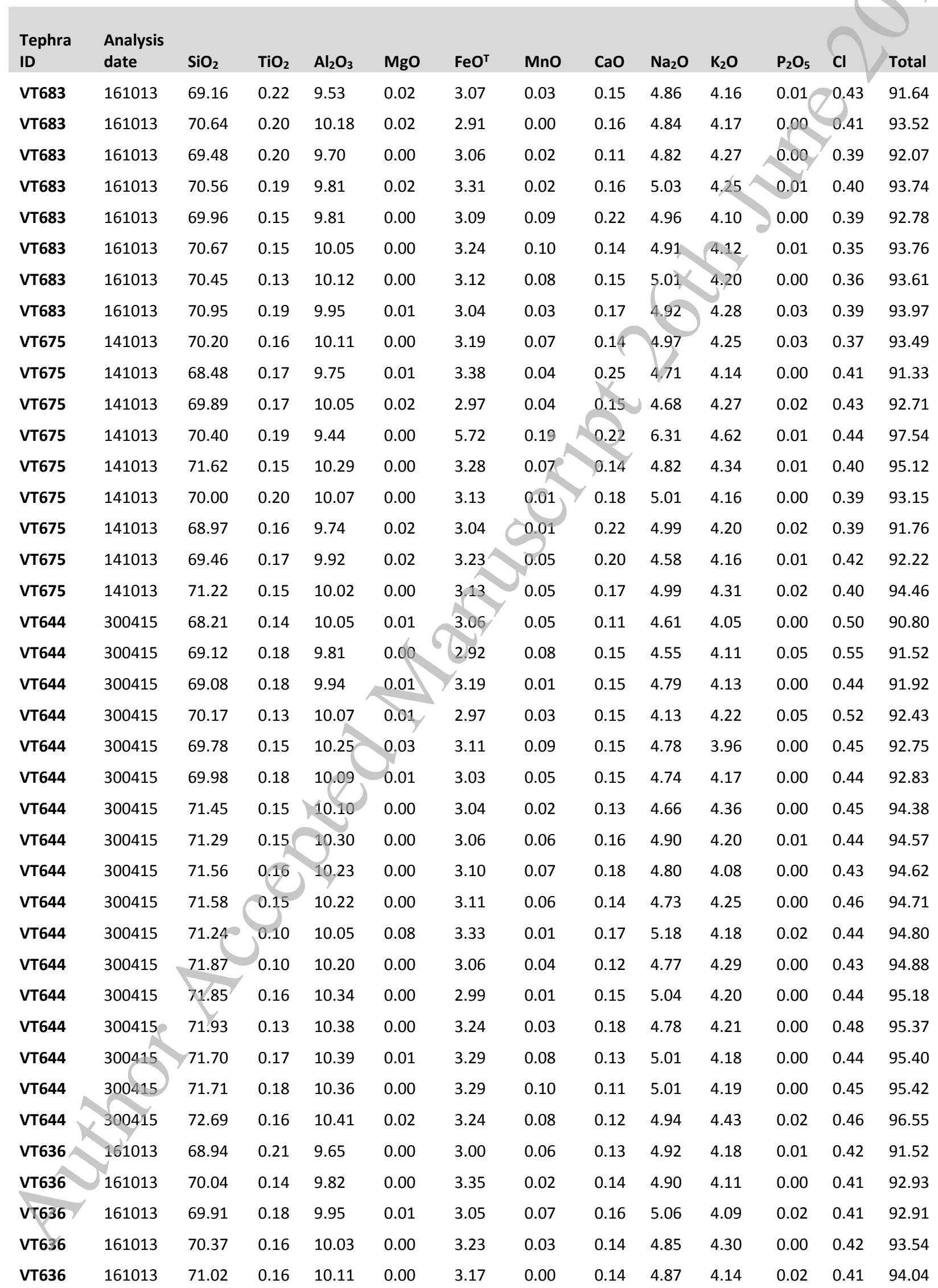




$\begin{array}{llllllllllllll}\text { VT636 } & 161013 & 70.61 & 0.10 & 10.08 & 0.02 & 3.20 & 0.07 & 0.17 & 4.87 & 4.21 & 0.00 & 0.39 & 93.71 \\ \text { VT636 } & 161013 & 71.15 & 0.12 & 10.18 & 0.00 & 3.28 & 0.00 & 0.14 & 4.81 & 4.19 & 0.02 & 0.41 & 94.28 \\ \text { VT636 } & 161013 & 70.16 & 0.16 & 9.93 & 0.00 & 3.21 & 0.00 & 0.16 & 5.06 & 4.14 & 0.01 & 0.37 & 93.21 \\ \text { VT22 } & 141013 & 70.37 & 0.22 & 8.01 & 0.00 & 6.12 & 0.15 & 0.26 & 6.83 & 4.25 & 0.01 & 0.59 & 96.80 \\ \text { VT22 } & 141013 & 70.36 & 0.23 & 8.05 & 0.00 & 5.99 & 0.18 & 0.26 & 6.61 & 4.24 & 0.00 & 0.51 & 96.45 / \\ \text { VT22 } & 141013 & 70.74 & 0.18 & 7.95 & 0.00 & 6.07 & 0.14 & 0.21 & 6.88 & 4.11 & 0.01 & 0.56 & 96.87 \\ \text { VT22 } & 141013 & 68.42 & 0.20 & 7.71 & 0.03 & 6.11 & 0.17 & 0.24 & 7.01 & 3.95 & 0.03 & 0.59 & 94.46 \\ \text { VT22 } & 141013 & 70.57 & 0.19 & 8.22 & 0.01 & 6.49 & 0.23 & 0.26 & 6.49 & 4.23 & 0.01 & 0.54 & 97.24 \\ \text { VT22 } & 141013 & 70.32 & 0.19 & 8.15 & 0.00 & 6.20 & 0.21 & 0.23 & 6.85 & 4.14 & 0.02 & 0.53 & 96.82 \\ \text { VT80 } & 161013 & 70.96 & 0.21 & 8.09 & 0.00 & 6.00 & 0.17 & 0.21 & 6.82 & 4.07 & 0.02 & 0.52 & 97.06 \\ \text { VT80 } & 300415 & 69.27 & 0.20 & 7.76 & 0.00 & 6.17 & 0.18 & 0.17 & 6.29 & 3.81 & 0.00 & 0.77 & 94.62\end{array}$

Table S2 Secondary standard analyses of MPI-DING fused volcanic glass standards, run intermittently during all Lake Victoria tephra glass shard EPMA runfiles to monitor instrument precision and accuracy. GeoRem assays for MPI-DING ATHO-G, StHIs6/80-G and GOR-132 glass standards after Jochum et al. $(2005,2006)$.

\begin{tabular}{|c|c|c|c|c|c|c|c|c|c|c|c|c|c|}
\hline $\begin{array}{l}\text { MPI-DING } \\
\text { standard }\end{array}$ & $\begin{array}{l}\text { Analysis } \\
\text { date }\end{array}$ & $\mathrm{SiO}_{2}$ & $\mathrm{TiO}_{2}$ & $\mathrm{Al}_{2} \mathrm{O}_{3}$ & $\mathrm{MgO}$ & $\mathrm{FeO}^{\top}$ & MnO & $\mathrm{CaO}$ & $\mathrm{Na}_{2} \mathrm{O}$ & $\mathrm{K}_{2} \mathrm{O}$ & $\mathrm{P}_{2} \mathrm{O}_{5}$ & $\mathrm{Cl}$ & Total \\
\hline ATHO-G & 141013 & 75.23 & 0.26 & 12.17 & 0.09 & 3.20 & 0.15 & 1.79 & 2.97 & 2.74 & 0.02 & 0.09 & 98.70 \\
\hline ATHO-G & 141013 & 75.02 & 0.25 & 12.32 & 0.09 & 3.15 & 0.09 & 1 & 3.96 & 2.72 & 0.02 & 0.03 & 99.39 \\
\hline ATHO-G & 141013 & 74.99 & 0.28 & 12.35 & 0.07 & 3.15 & 0.16 & 1.80 & 4.13 & 2.65 & 0.04 & 0.06 & 99.69 \\
\hline ATHO-G & 141013 & 75.46 & 0.23 & 12.29 & 0.12 & 3.50 & 0.15 & 1.62 & 4.14 & 2.79 & 0.01 & 0.05 & 100.36 \\
\hline ATHO-G & 161013 & 74.89 & 0.24 & 12.21 & 0.12 & 3.31 & 0.19 & 1.75 & 4.04 & 2.68 & 0.03 & 0.03 & 99.49 \\
\hline ATHO-G & 161013 & 74.55 & 0.25 & 11.86 & 0.10 & 3.35 & 0.04 & 1.73 & 4.34 & 2.71 & 0.03 & 0.04 & 99.03 \\
\hline ATHO-G & 161013 & 74.53 & 0.27 & 12.01 & 0.10 & 3.1 & 0.13 & 1.73 & 4.04 & 2.78 & 0.02 & 0.05 & 98.80 \\
\hline ATHO-G & 300415 & 75.04 & 0.25 & 12.01 & & 3.17 & 0.07 & 1.73 & 3.96 & 2.77 & 0.04 & 0.04 & 99.14 \\
\hline ATHO-G & 300415 & 74.75 & 0.23 & 12.09 & & 2.95 & 0.10 & 1.70 & 4.07 & 2.65 & 0.02 & 0.08 & 98.70 \\
\hline ATHO-G & 300415 & 74.11 & 0.25 & 12.06 & .1 & 2.96 & 0.05 & 1.74 & 4.17 & 2.70 & 0.00 & 0.04 & 98.18 \\
\hline ATHO-G & 300415 & 74.72 & 0.25 & 12.06 & 0.10 & 3.07 & 0.09 & 1.72 & 4.29 & 2.69 & 0.00 & 0.03 & 99.03 \\
\hline ATHO-G & 300415 & 74.60 & 0.25 & 11.91 & 0.06 & 3.05 & 0.12 & 1.66 & 4.12 & 2.76 & 0.00 & 0.03 & 98.56 \\
\hline ATHO-G & 300415 & 75.34 & 0.25 & 12.49 & 0.07 & 3.38 & 0.07 & 1.61 & 4.33 & 2.69 & 0.00 & 0.07 & 100.30 \\
\hline \multirow[t]{4}{*}{ ATHO-G } & 300415 & 75.74 & 0.26 & 12.20 & 0.07 & 3.23 & 0.17 & 1.66 & 4.22 & 2.68 & 0.03 & 0.04 & \multirow[t]{4}{*}{100.30} \\
\hline & Average & 74.93 & 0.25 & 12.15 & 0.09 & 3.19 & 0.11 & 1.71 & 4.06 & 2.71 & 0.02 & 0.05 & \\
\hline & $2 \sigma$ & 0.86 & 0.03 & 0.36 & 0.05 & 0.33 & 0.09 & 0.11 & 0.67 & 0.09 & 0.03 & 0.04 & \\
\hline & GeoReM & 75.60 & 0.26 & 12.20 & 0.10 & 3.27 & 0.11 & 1.70 & 3.75 & 2.64 & 0.04 & 0.03 & \\
\hline $\begin{array}{l}\text { MPI-DING } \\
\text { standard }\end{array}$ & $\begin{array}{l}\text { Analysis } \\
\text { date }\end{array}$ & $\mathrm{SiO}_{2}$ & $\mathrm{TiO}_{2}$ & $\mathrm{Al}_{2} \mathrm{O}_{3}$ & MgO & $\mathrm{FeO}^{\top}$ & $\mathrm{MnO}$ & $\mathrm{CaO}$ & $\mathrm{Na}_{2} \mathrm{O}$ & $\mathrm{K}_{2} \mathrm{O}$ & $\mathrm{P}_{2} \mathrm{O}_{5}$ & Cl & Total \\
\hline StHs6/80-G & 14101 & 62.90 & 0.69 & 17.60 & 2.04 & 4.35 & 0.00 & 5.28 & 4.53 & 1.32 & 0.18 & 0.00 & 98.88 \\
\hline StHs6/80-G & 141013 & 63.62 & 0.77 & 17.81 & 1.99 & 4.46 & 0.14 & 5.27 & 4.71 & 1.27 & 0.16 & 0.02 & 100.23 \\
\hline StHs6/80-G & 141013 & 63.54 & 0.69 & 17.74 & 1.92 & 4.04 & 0.03 & 5.29 & 4.80 & 1.34 & 0.14 & 0.02 & 99.54 \\
\hline StHs6/80-G & 141013 & 63.05 & 0.75 & 17.52 & 1.93 & 4.18 & 0.11 & 5.16 & 4.61 & 1.27 & 0.14 & 0.02 & 98.74 \\
\hline Str & 161013 & 63.40 & 0.77 & 17.52 & 1.94 & 4.39 & 0.08 & 5.16 & 4.66 & 1.30 & 0.17 & 0.00 & 99.39 \\
\hline StHs6/80 & 161013 & 63.43 & 0.74 & 17.61 & 2.01 & 4.22 & 0.04 & 5.22 & 4.53 & 1.35 & 0.14 & 0.00 & 99.28 \\
\hline StHs6/80-G & 161013 & 63.21 & 0.70 & 17.49 & 1.99 & 4.13 & 0.00 & 5.24 & 4.36 & 1.31 & 0.16 & 0.02 & 98.62 \\
\hline StHs6/80-G & 161013 & 63.28 & 0.71 & 17.37 & 1.93 & 4.34 & 0.08 & 5.02 & 4.55 & 1.26 & 0.15 & 0.00 & 98.69 \\
\hline StHs $6 / 80-G$ & 300415 & 63.61 & 0.74 & 17.75 & 1.98 & 4.38 & 0.06 & 5.18 & 4.55 & 1.26 & 0.13 & 0.01 & 99.65 \\
\hline StHs6/80-G & 300415 & 63.84 & 0.74 & 17.69 & 2.06 & 4.34 & 0.12 & 5.24 & 4.53 & 1.29 & 0.22 & 0.03 & 100.10 \\
\hline
\end{tabular}




\begin{tabular}{|c|c|c|c|c|c|c|c|c|c|c|c|c|c|}
\hline StHs6/80-G & 300415 & 63.81 & 0.71 & 17.69 & 1.98 & 4.40 & 0.04 & 5.26 & 4.51 & 1.25 & 0.15 & 0.02 & 99.82 \\
\hline StHs6/80-G & 300415 & 63.69 & 0.75 & 17.54 & 1.96 & 4.18 & 0.05 & 5.27 & 4.58 & 1.26 & 0.10 & 0.02 & 99.39 \\
\hline StHs6/80-G & 300415 & 63.45 & 0.71 & 17.47 & 1.92 & 4.20 & 0.04 & 5.24 & 4.29 & 1.33 & 0.12 & 0.00 & 98.78 \\
\hline StHs6/80-G & 300415 & 63.38 & 0.74 & 17.57 & 1.88 & 4.41 & 0.10 & 5.19 & 4.43 & 1.35 & 0.16 & 0.02 & 99.23 \\
\hline \multirow[t]{4}{*}{ StHs6/80-G } & 300415 & 63.21 & 0.75 & 17.42 & 1.89 & 4.37 & 0.10 & 5.25 & 4.50 & 1.32 & 0.17 & 0.01 & \\
\hline & Average & 63.43 & 0.73 & 17.58 & 1.96 & 4.29 & 0.07 & 5.22 & 4.54 & 1.30 & 0.15 & 0.01 & \\
\hline & $2 \sigma$ & 0.54 & 0.06 & 0.25 & 0.10 & 0.25 & 0.09 & 0.14 & 0.26 & 0.07 & 0.05 & 0.02 & \\
\hline & GeoReM & 63.70 & 0.70 & 17.80 & 1.97 & 4.37 & 0.08 & 5.28 & 4.44 & 1.29 & 0.16 & 0.01 & \\
\hline $\begin{array}{l}\text { MPI-DING } \\
\text { standard }\end{array}$ & $\begin{array}{l}\text { Analysis } \\
\text { date }\end{array}$ & $\mathrm{SiO}_{2}$ & $\mathrm{TiO}_{2}$ & $\mathrm{Al}_{2} \mathrm{O}_{3}$ & MgO & $\mathrm{FeO}^{\top}$ & MnO & $\mathrm{CaO}$ & $\mathrm{Na}_{2} \mathrm{O}$ & $\mathrm{K}_{2} \mathrm{O}$ & $\mathrm{P}_{2} \mathrm{O}_{5}$ & & Total \\
\hline GOR132-G & 141013 & 45.59 & 0.31 & 10.84 & 22.16 & 9.94 & 0.10 & 8.46 & 0.80 & 0.04 & 0.03 & 0.0 & 98.28 \\
\hline GOR132-G & 141013 & 45.69 & 0.27 & 10.93 & 22.23 & 9.95 & 0.11 & 8.26 & 0.84 & 0.04 & & 0. & 98.40 \\
\hline GOR132-G & 141013 & 45.47 & 0.28 & 10.91 & 21.89 & 9.91 & 0.11 & 8.40 & 0.80 & 0.04 & 0.03 & 0.00 & 97.82 \\
\hline GOR132-G & 161013 & 45.37 & 0.34 & 10.63 & 22.22 & 9.84 & 0.14 & 8.54 & 0.92 & 0.02 & 0.04 & 0.00 & 98.06 \\
\hline GOR132-G & 161013 & 45.66 & 0.31 & 10.62 & 22.39 & 10.41 & 0.27 & 8.51 & 0.79 & 0.03 & 0.05 & 0.00 & 99.03 \\
\hline GOR132-G & 300415 & 44.86 & 0.25 & 10.77 & 22.46 & 10.40 & 0.08 & 8.56 & 0.75 & 0.07 & 0.07 & 0.01 & 98.27 \\
\hline GOR132-G & 300415 & 44.78 & 0.27 & 10.75 & 22.48 & 10.11 & 0.15 & 8.61 & 1.02 & 0.04 & 0.03 & 0.00 & 98.25 \\
\hline GOR132-G & 300415 & 44.73 & 0.32 & 10.54 & 22.26 & 10.12 & 0.11 & 8.59 & 0.80 & 0.00 & 0.06 & 0.02 & 97.56 \\
\hline GOR132-G & 300415 & 45.08 & 0.30 & 10.68 & 22.58 & 10.58 & 0.11 & 8.57 & 0.74 & 0.00 & 0.04 & 0.02 & 98.68 \\
\hline GOR132-G & 300415 & 45.24 & 0.23 & 10.83 & 22.23 & 10.36 & 0.15 & 8.62 & 0.78 & 0.03 & 0.03 & 0.00 & 98.49 \\
\hline \multirow[t]{4}{*}{ GOR132-G } & 300415 & 45.20 & 0.28 & 10.66 & 22.24 & 10.17 & 0.17 & 8.43 & 0.84 & 0.01 & 0.04 & 0.02 & 98.06 \\
\hline & Average & 45.24 & 0.29 & 10.74 & 22.28 & 10.16 & 0.14 & 8.50 & 0.82 & 0.03 & 0.04 & 0.01 & \\
\hline & $2 \sigma$ & 0.70 & 0.06 & 0.25 & 0.38 & 0.49 & 0.10 & 0.22 & 0.16 & 0.04 & 0.03 & 0.02 & \\
\hline & GeoReM & 45.39 & 0.30 & 10.87 & 22.27 & 10.30 & 0.15 & 8.45 & 0.79 & 0.03 & 0.04 & 0.01 & \\
\hline
\end{tabular}




\section{Supplementary Data File 2}

\section{V95-1P Age Model Construction}

Table S3: Radiocarbon dates for V95-1P, made on pollen, macrofossils and bulk sediment samples used in this study to construct a new Bayesian-based depositional model. References refer to the original publication for each age estimate. All dates were calibrated using IntCal13 (Reimer et al., 2013). Dates above a boundary placed at the onset of diatomaceous mud accumulation $(610 \mathrm{~m})$ were modelled using the P_Sequence function in OxCal version 4.3 (Ramsey et al., 2009, 2009). Age estimates within the palaeosol sediments are calibrated and excluded from the model due to the apparent age inconsistencies.

\begin{tabular}{|c|c|c|c|c|c|c|}
\hline $\begin{array}{l}\text { Depth } \\
(\mathrm{cm})\end{array}$ & $\begin{array}{l}\text { 14C age } \\
\text { (yrs BP) }\end{array}$ & \pm 1 sd & Material & \begin{tabular}{|c|} 
Calibrated \& \\
modelled age \\
(yrs BP, $95.4 \% \mathrm{CL}$ )
\end{tabular} & $\begin{array}{c}\text { Sample } \\
\text { Code }\end{array}$ & \\
\hline 5 & 1420 & 70 & pollen & $1517-1182$ & Trond 4/98 & Johnson et al., 2000 \\
\hline 101 & 3060 & 35 & Sediment organic ca & $3360-3178$ & OS-77334 & Berke et al., 2012 \\
\hline 199 & 4595 & 75 & pollen & $5475-5040$ & Trond 4/98 & Johnson et al., 2000 \\
\hline 318.5 & 6700 & 110 & pollen & $7786-7431$ & Trond 4/98 & Johnson et al., 2000 \\
\hline 398 & 8380 & 70 & pollen & 9531-9271 & Trond 4/98 & Johnson et al., 2000 \\
\hline 474 & 10000 & 40 & Sediment organic carbon & $11694-11276$ & OS-77335 & Berke et al., 2012 \\
\hline 548 & 11635 & 160 & pollen & $13731-13188$ & Trond 4/98 & Johnson et al., 2000 \\
\hline 568 & 12180 & 185 & pollen & $14297-13583$ & Trond 1/99 & Johnson et al., 2000 \\
\hline \multicolumn{4}{|c|}{ Palaeosol levels: } & $\begin{array}{c}\text { Calibrated age } \\
\text { (yrs BP, 95.4\% CL) }\end{array}$ & & \\
\hline 652 & 14450 & 65 & Sediment organic carbon & $17,863-17,414$ & OS-77351 & Berke et al., 2012 \\
\hline 716 & 13600 & 55 & Plant / wood fragment & $16653-16,200$ & OS-77314 & Berke et al., 2012 \\
\hline 772 & 17300 & 75 & Bulk organic carbon & $21,089-20,603$ & OS-77350 & Berke et al., 2012 \\
\hline 859 & 16760 & 140 & unspecified & 20,585-19,870 & Beuning7/96 & Berke et al., 2012 \\
\hline 884 & 14600 & 60 & Bulk organic carbo & $17,969-17,593$ & OS-77336 & Berke et al., 2012 \\
\hline 903 & 14100 & 95 & unspecified & $17,475-16,827$ & Trond 1/99 & Johnson et al., 2000 \\
\hline
\end{tabular}

OxCal P_Sequence age model code:
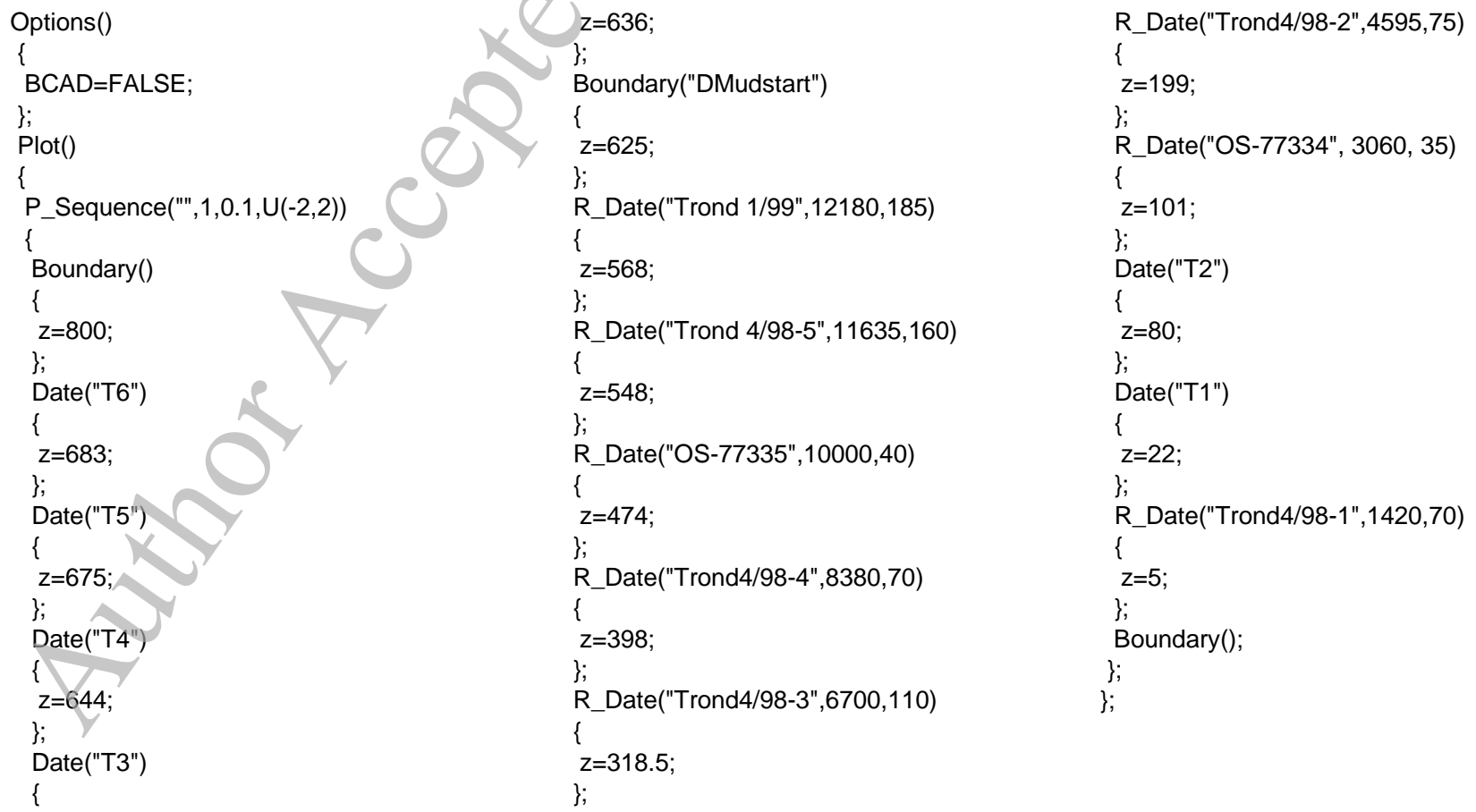